Article

\title{
Does MOOC Quality Affect Users' Continuance Intention? Based on an Integrated Model
}

\author{
Wei Gu ${ }^{1, *(D)}$, Ying $\mathrm{Xu}^{2}$ and Zeng-Jun Sun ${ }^{2}$ \\ 1 School of Economics and Management, Zaozhuang University, Zaozhuang 277160, China \\ 2 Department of Global Distribution and Marketing, Namseoul University, Cheonan 31020, Korea; \\ seoyoung835@hotmail.com (Y.X.); s1982@nsu.ac.kr (Z.-J.S.) \\ * Correspondence: earily@kongju.ac.kr
}

check for

updates

Citation: Gu, W.; Xu, Y.; Sun, Z.-J. Does MOOC Quality Affect Users' Continuance Intention? Based on an Integrated Model. Sustainability 2021, 13, 12536. https://doi.org/10.3390/ su132212536

Academic Editors: María

Soledad Ramírez Montoya,

Ebba Ossiannilsson, Arturo Molina

Gutiérrez and Jane-Frances Agbu

Received: 6 October 2021

Accepted: 10 November 2021

Published: 12 November 2021

Publisher's Note: MDPI stays neutral with regard to jurisdictional claims in published maps and institutional affiliations.

Copyright: (C) 2021 by the authors. Licensee MDPI, Basel, Switzerland. This article is an open access article distributed under the terms and conditions of the Creative Commons Attribution (CC BY) license (https:// creativecommons.org/licenses/by/ $4.0 /)$.

\begin{abstract}
Massive open online course (MOOC) is an innovative educational model that has attracted widespread attention in recent years. Despite a growing number of registered users, many have given up continuously using MOOC platforms after the first-time user experience; thus, a high dropout rate has severely hindered the sustainable development of MOOC platforms. To address the problem, this study started with the quality factors of MOOC platforms and the confirmation of user expectations by integrating the D\&M ISS model and the expectation confirmation model into one, with the goal of identifying the factors that affect users' continuance intention to use MOOC platforms. In this study, online questionnaires were distributed to Chinese users with experience in using MOOC platforms, and a total of 550 valid samples were recovered. In addition, the theoretical model was tested using structural equation modeling (SEM). The research results showed that there are three critical antecedents affecting the confirmation of user expectations for a MOOC platform, including information quality, system quality, and service quality, of which service quality has the greatest impact on users' expectation confirmation. If user expectations for an MOOC platform are positively confirmed, the perceived usefulness of the platform as well as the satisfaction with it will effectively be improved. Moreover, perceived usefulness has been proven to be a critical factor affecting users' continuance intention to use MOOC platforms, which is followed by user satisfaction. Compared to the original ECM, the integrated research model has delivered significantly improved explanatory power for users' continuance intention. Hence, this study makes up for the insufficiency of ECM in explaining the factors affecting users' expectation confirmation and provides theoretical support for MOOC platform developers.
\end{abstract}

Keywords: MOOC platforms; quality factors; expectation confirmation; D\&M ISS model; ECM; continuance intention

\section{Introduction}

Education plays a vital role in promoting human progress and sustainable development [1,2], especially when current widespread attention has been attached to how to solve unsustainable problems in society through education [3-5]. With the advancement of information and communication technology, education is integrating with technology, thereby changing the traditional way of education [6]. As a result, teachers and students are provided with an increasing number of teaching and learning options under the support of mature technology [7], of which massive open online course (MOOC) is attracting more and more attention $[8,9]$.

In 2001, the Massachusetts Institute of Technology (MIT) launched the Open Educational Resources Movement, which laid the foundation for the development of MOOCs. In 2011, Stanford University offered AI courses that attracted more than 160,000 people to participate online, bringing about the first breakthrough of MOOCs [10]. Subsequently, typical MOOC platforms emerged one after another in the United States, including Coursera, edX, Udacity, and more. Compared to traditional education methods, internet-based 
MOOC platforms are free from the limitation of time and space, allowing users to receive educational services anytime and anywhere, through mobile devices, computers, networks, etc. [11,12].

MOOCs get rid of the limitation of traditional education models and, therefore, are regarded as innovative $[13,14]$. While breaking the traditional model of offline classroom teaching, MOOC provides learners with an additional learning method [15]. According to Class Central research reports, as of 2019, there had been over 900 colleges and universities worldwide launched MOOCs, with the total number of courses launched reaching 13,500 and the total number of registered learners reaching 101 million, an increase rate of $29.5 \%$ [16]. It can be seen that the MOOC education model is being increasingly accepted. Meanwhile, the learning results on MOOC platforms are gradually being recognized by traditional universities and governments. As an example, in China, The Ministry of Education of China issued the Opinions on Strengthening Construction, Application and Management of Online Open Courses in Colleges and Universities in 2015, for the purpose of encouraging colleges and universities in China to recognize the credits earned by students on MOOC platforms [17]. As of December 2019, an array of colleges and universities in China, such as China Pharmaceutical University, China University of Geosciences, and Jiangxi University of Science and Technology, have recognized the academic performance and credits of students in certified courses on Coursera, EDX, Udacity, Icourse163, and other MOOC platforms, which are accepted as public electives. Although the measures such as certificate issuance and credit recognition taken by MOOC providers and government departments uplift the effectiveness of MOOCs and the enrollment rate of students to a certain degree, a high dropout rate seems to be a common feature of many MOOCs [18-20]. Studies have shown that the dropout rate of MOOCs is as high as $90 \%$; and most of the learners abandon course learning after their initial experience [21-23]. However, the ultimate success of an MOOC platform relies on the continued enrollment of learners [24,25], which promises to bring considerable benefits to MOOC platforms and reduce advertisement costs [26]. Therefore, such a high dropout rate has seriously hindered the sustainable development of the MOOC industry [20,21,27-29].

With the increasing acceptance of the open education model of MOOCs and the concept of lifelong learning, growing attention from the academic community has been paid to whether MOOCs can promote the sustainable development of education $[10,27,30,31]$. An MOOC platform is a network-based learning system, so users' continuance intention depends largely on user satisfaction, which is also considered to be one of the factors that evaluates the success of an information system (IS) [13,32-35]. The expectation confirmation model (ECM) believes that user satisfaction to a large extent is determined by expectation confirmation [33]. If the expectation of users is confirmed after the use of a system, it has a positive impact on user satisfaction, which in turn promotes continuance intention $[33,36,37]$. However, the original ECM fails to analyze the external factors affecting expectation confirmation, which limits the predictive ability of the model [38-40]. In view of this, some studies have introduced the quality factors constructed by the information systems success model (D\&M ISS model) as the preceding factors affecting expectation confirmation, in an attempt to make up for the aforesaid shortcoming [39-42]. The combined ECM with the D\&M ISS model better explains users' behavior of continuously using ISs $[39,43,44]$. Nonetheless, to the best of our knowledge, a scarcity of studies apply the combination of the ECM and the D\&M ISS model to investigate users' continuance intention to use MOOC platforms. Therefore, in the context of MOOCs, this paper proposes a research framework that combines the D\&M ISS model and the ECM, with the goal of identifying the causal relationship between the quality factors of MOOC platforms and the confirmation of user expectations, and thus exploring the preceding factors that affect continuance intention. While making up for the gap in previous studies, our research results are expected to provide a theoretical basis for the sustainable development of the MOOC industry. 


\section{Research Background}

\subsection{Massive Open Online Courses}

The definition of MOOC is derived from the combination of e-learning, large-scale communication, knowledge sharing, and openness [45]. Generally speaking, MOOCs are to spread and share knowledge via information and communication technology, emphasizing the scale and openness of courses that target all potential learners [22,45]. Learners not only can obtain course resources anytime and anywhere via MOOC platforms, they can also perform online exchanges, communication, and interaction [46].

MOOC is a concept first proposed by Bryan Alexander and Dave Cormier used to refer to the public course "Connectivism and Connective Knowledge" (CCK08) [13] that was lectured in Canada by Stephen Downes and George Siemens in 2008. Different from traditional online distance learning, CCK08 underscored more the openness and scalability of courses. The milestone that indicates MOOC having gained the wide attention of the public is the success of the online open course "Artificial Intelligence" lectured by Professor Sebastian Thrun at Stanford University in 2011, which attracted more than 160,000 students from more than 190 countries worldwide. Inspired by this success, a large number of MOOC platforms emerged one after another, such as Coursera, Udacity, and edX, a nonprofit organization, that develops courses in cooperation with world-class universities to provide learners with free courses and value-added paid services. As a result of the growing popularity of MOOC platforms in the United States, MOOC has been spread to many other countries, where this education model sees further development. According to statistics, there have been at least 40 MOOC platform operators worldwide [47].

At this stage, the development of MOOC platforms is mainly based on Connective MOOC (cMOOC) and Extended MOOC (xMOOC) [48]. The former, established on connectivism [49], does not emphasize teacher-generated content but instead contributes to the creation and construction of knowledge by inviting learners [49,50]. Differently, the latter, established on content-based cognitive behaviorism, highlights cooperation with prestigious universities, whose experts and scholars or teachers undertake curriculum development, while learners complete the learning goals of each course in a linear manner [48]. Noticeably, the three representative MOOC platforms, including Coursera, edX, and Udacity all use the xMOOC model [51]. Taking Coursera as an example, the platform cooperates with well-known universities to develop courses, whose content information and schedule can be obtained before they are offered. In these courses, quizzes, after-class assignments, mid-term and final exams are to be set up [52]. Meanwhile, xMOOC is in favor of the teaching methods adopted by traditional higher education institutions, so that it is generally used by the latter as a supplement to their online teaching [50].

The growing emergence of MOOCs gives birth to an increasing number of academic research thereon [53]. MOOC is considered as a more advanced form of higher education, and its learning model is more similar to the openness of individuals naturally revealed in daily life [54]. In traditional higher education, MOOCs are expected to improve students 'academic performance and help freshmen to catch up with university courses [55]. Li et al. [56] studied 23 representative MOOC platforms and concluded that these platforms had a varying number of users ranging from 10 thousand to 5 million and most of them had developed their mobile APP and that the credits of some MOOCs developed in cooperation with traditional educational institutions were recognized by colleges and universities. Most researchers believe that the education model in MOOCs can effectively reduce the learning costs of students and solve the problem of teacher shortage in many regions, especially in developing countries, thereby increasing the opportunities of common people to access to education [57-59].

However, the education community casts doubts over whether MOOC platforms can achieve sustainable development considering the unsatisfactory dropout rate of MOOC platform learners and the miscellaneous quality of services provided by platform operators [53]. MOOC platforms are web-based learning information systems, so their sustainability depends largely on users' continuance intention, which is considered to be one of 
the indicators to evaluate whether an MOOC platform is successful [23]. Therefore, this study holds that apart from the efforts of promotion and advertisement, MOOC platforms should strive to understand user satisfaction after the first use, so as to effectively expand and optimize services.

\subsection{DeLone and McLean Information Systems Success Model (DEM ISS Model)}

The original D\&M ISS model [60] consisted of six factors that affect the success of an IS proposed by DeLone and McLean in 1992 based on the research of Mason [61] on Shannon and Weaver [62] in communication mathematical theory. These six factors include (1) system quality, (2) information quality, (3) IS use, (4) user satisfaction, (5) individual impact, and (6) organizational impact. With the emergence and explosive growth of e-commerce, IS practice has changed dramatically. In 2004, DeLone and McLean updated the research model and evaluated its effectiveness [32]. The updated D\&M ISS model added service quality as a new dimension of successful ISs, and combined all "influential" measures into a single impact or net benefit. The D\&M ISS model considers system quality, information quality, and service quality as the key factors for users to determine whether or not to continuously use an IS, while the quality of the IS determines users' use efficiency and personal outcomes [32].

The updated D\&M ISS model is widely applied to the research on information systems in different fields $[63,64]$, and the information quality, service quality, and system quality it constructs are also considered as the indicators to determine whether or not an e-learning system is successful [65]. Based on the D\&M ISS model, Al-Fraihat et al. [10] developed a multi-dimensional success model for e-learning systems, in which quality is taken as the main factor that drives users to continuously use e-learning systems. Cidral et al. [66] deemed the D\&M ISS model's quality factor as the preceding factor that affects users' continuance intention to use e-learning systems. Furthermore, they evaluated the success of e-learning systems. In addition, research on continuance intention to use e-learning systems also shows that the quality dimension of the D\&M ISS model is an important factor influencing users' continuance intention to use e-learning systems [67-69]. Therefore, this study considers that for MOOC platforms as a kind of e-learning system, the precondition to gain success is to have excellent platform quality, which can effectively improve users' psychological perception of services. Based on the external factors constructed by the D\&M ISS model (e.g., information quality, service quality and system quality), this study strives to develop the quality factor of MOOC platforms.

\subsection{Expectation Confirmation Model (ECM)}

The Expectation confirmation model, first proposed by Bhattacherjee in 2001 based on expectation confirmation theory [70], revolves around the interconnection between users' cognitive beliefs and the formation of their continuance intention to use e-learning systems [33]. According to the ECM, the initial enrollment of learners is only the first step of success for an e-learning system, and the key thereof lies in maintaining users' willingness for continuous use, in which confirmation of user expectations, perceived usefulness, and user satisfaction are considered to be the key factors affecting their willingness [71]. ECM claims that users have different expectations upon ISs before and after adoption, while perceived performance is the psychological reflection of user expectations after adoption; perceived performance and satisfaction of users increase or decrease with the degree of expectation confirmation, further affecting the formation of their continuance intention [72].

Since its development, the ECM has been widely used to study users' continuance intention to use ISs, including ERP systems [73], e-learning systems [6], e-government [43], mobile social commerce [37], and mobile applications [74]. For example, Kim et al. [75] integrated the value-based adoption model and the ECM together to investigate users' continuance intention to use accommodation-related mobile phone software. The results showed that users' expectation confirmation after the first use of a mobile phone software product had a significant impact on their perceived usefulness and satisfaction and that 
user satisfaction demonstrated the strongest impact on users' willingness for continued use. Cheng [39] used the ECM to study the continuance intention to use e-learning systems, and detected that expectation confirmation affected users' perceived performance and satisfaction with e-learning systems, which, in turn, affect their continuance intention. However, some studies questioned the accuracy of the above results, claiming that the ECM fails to fully consider the impact of external factors on the confirmation of user expectations, which may limit the prediction accuracy of the model $[38,39,43,76]$. In view of this, we expanded the quality factor constructed by the D\&M ISS model as an external factor of expectation confirmation, in an attempt to better understand the continuous use behaviors of users in a MOOC context.

\section{Research Model and Hypothesis}

\subsection{Research Model}

This study establishes a theoretical model based on the ECM and the quality factors of the D\&M ISS model, and attempts to examine the role that information quality, system quality, and service quality as the preceding factors affect the confirmation of user expectations play in the formation of users' continuance intention to use MOOC platforms. The research model is advanced as indicated in Figure 1.

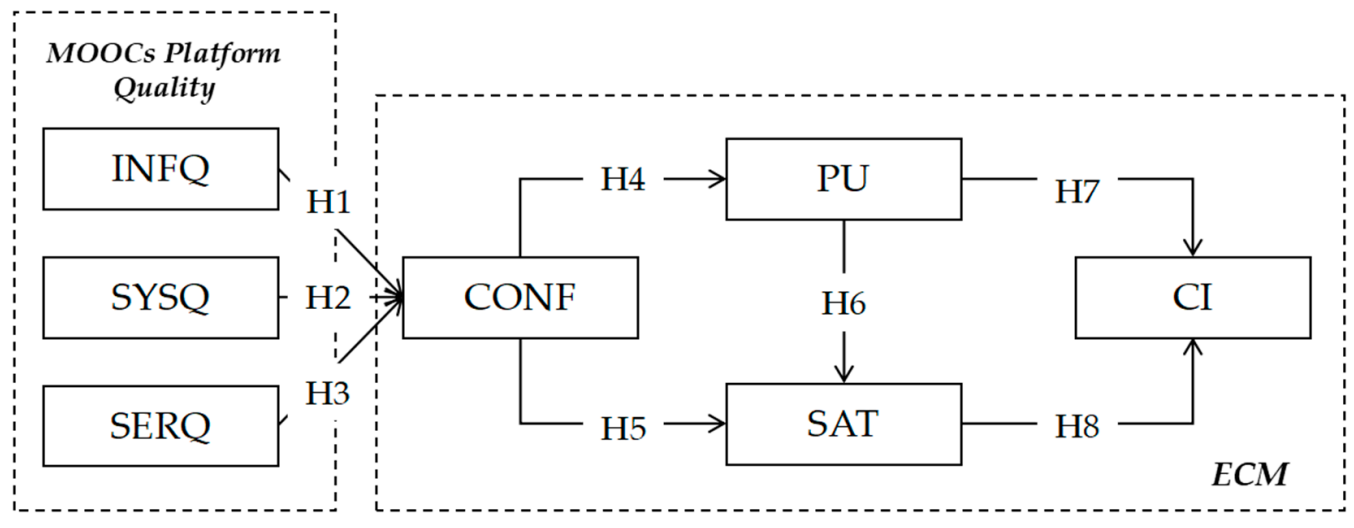

Figure 1. Research model. Note: INFQ: Information quality, SYSQ: System quality, SERQ: Service quality, CONF: Confirmation, PU: Perceived usefulness, SAT: Satisfaction, and CI: Continuance Intention.

\subsection{Research Hypothesis}

Delone and Mclean pointed out that the key to driving users to continuously use ISs is the quality factor, which, as they suggested, should include three aspects, i.e., information quality, system quality, and service quality [32]. Information quality is determined by both the source and content of the information provided by ISs, reflecting the accuracy, effectiveness, and versatility of system contents; system quality corresponds to the technical characteristics, performance, and availability of a system itself; while service quality is associated with the capacities of IS developers in response and perception and generally described as the degree of matching between the service level delivered by IS developers and user expectations [32,77].

The quality factor constructed by the D\&M ISS model as the precondition of IS success has been widely used in the research on ISs. With e-learning systems as an example, Cidral et al. [66] verified the importance of system quality, information quality, and service quality in affecting users' psychological perception. They reported that the degree of conformity of platform quality to user expectations positively influenced users' continuance intention to use ISs. In addition, Cheng [39] took system quality, information quality, and service quality as the preconditions of users' continuance intention to use e-learning systems and concluded that the quality factor of IS affected the confirmation of user expectations [38]. Studies have shown that if users perceive the quality of an e-learning system as exceeding their expectations, they respond positively to the e-learning 
system. Therefore, this study concludes that the high-level platform qualities (including information quality, system quality, and service quality) provided by MOOC operators have a positive impact on expectation confirmation. Based on this, we proposed the following hypotheses:

Hypothesis 1 (H1). The information quality of a MOOC platform positively affects users' confirmation.

Hypothesis 2 (H2). The system quality of a MOOC platform positively affects users' confirmation.

Hypothesis 3 (H3). The service quality of a MOOC platform positively affects users' confirmation.

In addition, according to the ECM, user satisfaction is an important component of predicting continuance intention, while the degree of user satisfaction depends on expectations and perceived usefulness of the product or service bought. These connections come from the theory of cognitive dissonance [33,78]. Moreover, Bhattacherjee believed that users generate initial expectations before using an IS and they confirm their expectations based on the actual experience. If an IS outperforms expectations, users generate positive emotional responses to it, which in turn positively affects perceived performance and user satisfaction. A large number of studies on IS continuation have shown that it is feasible to apply the ECM to study users' continuance intention to use a product [44,79]. Akram et al. [44] investigated the determinants of users' continuance intention to use mobile banking services using an extended ECM, and concluded that the confirmation following the first use of the mobile banking services had a significant impact on perceived performance and user satisfaction. Hung et al. [80] explored the willingness of university teachers to continuously use e-learning systems using an ECM and detected that confirmation would affect perceived performance and post-use satisfaction, which consequently influence users' continuance intention. In view of the above, this study puts forward the following hypotheses based on the ECM:

Hypothesis 4 (H4). Confirmation positively affects perceived usefulness of an MOOC platform.

Hypothesis 5 (H5). Confirmation positively affects satisfaction of an MOOC platform.

Hypothesis 6 (H6). Perceived usefulness positively affects satisfaction of an MOOC platform.

Hypothesis 7 (H7). Perceived usefulness positively affects continuance intention of an MOOC platform.

Hypothesis 8 (H8). Satisfaction positively affects continuance intention of an MOOC platform.

\section{Methodology}

\subsection{Questionnaire and Pre-Test}

This study includes 7 constructs and 28 question items, and the measurements of all constructs refer to existing research. Specifically, the items on information quality, system quality, and service quality come from the studies by Delone and Mclean [32] and Aparicio et al. [34]; confirmation items refer to the studies by Liao et al. [71], Cheng [39], and Bhattacherjee [33]; both perceived usefulness and satisfaction items refer to the studies by Bhattacherjee [32] and Liao et al. [71]; and continuance intention items come from the studies by Bhattacherjee [33], Cheng [39], and Lin and Wang [81].

In order to ensure that all items are suitable for the MOOC environment, five professors in the field of pedagogy and information system management were invited to evaluate whether there is a deviation in the measured questions. Then, a pre-survey was performed on 30 undergraduates with experience in at least one MOOC platform. According to the results of the pre-survey and the recommendations from the professors, slight modifications to the wording of the questions were made with their original intent unchanged. Ultimately, a final 
questionnaire was designed. All questions were statistically analyzed by the 7-point Likert scale, where, "1" indicates "strongly disagree" and "7" "strongly agree". See Appendix A.

\subsection{Data Collection and Analysis Method}

Using a convenient sampling method, this study surveyed Chinese learners who were enrolled in at least a course in MOOC platforms including Coursera, Edex, Udacity, and Icourse163. The questionnaires were distributed online from October to December 2019. There were a total of 550 valid questionnaires collected. The questionnaire data collected were statistically analyzed using SPSS 24 (SPSS Inc., Chicago, IL, USA) and AMOS 24 (SPSS Inc., Chicago, IL, USA). First of all, a frequency analysis was performed to identify the demographic characteristics of the respondents. Then, partial least squares regression (PLS regression) was adopted to process the data collected, and the fitness and structural validity of the proposed measurement model was tested by evaluating its reliability, convergence validity, and discrimination validity. Finally, the hypotheses proposed were verified by a structural equation model [82].

\subsection{Sample Characteristics}

According to descriptive demographic characteristics, the respondents had a balanced gender distribution, including $42 \%$ of males and $58 \%$ of females, mainly falling into the two age groups, $19-28(28.7 \%)$ and $29-38$ (55.6\%). In terms of educational background, more than $90 \%$ of the respondents had a bachelor's degree or higher. In terms of use time of MOOC platforms, the proportions of the respondents who had use time of less than 6 months, 6-12 months, and longer than 1 year were $34.9 \%, 56.9 \%$, and $8.2 \%$, respectively. Additionally, the main MOOC platforms used include Icourse163 (52.2\%), Coursera $(25.6 \%)$, Udacity $(14.2 \%)$ and Edex $(8 \%)$. The sample traits are basically consistent with the characteristics of the main users of MOOC platforms in China. Therefore, the sample data collected in this study were suitable for empirical analysis. Table 1 presents the respondents' profile.

Table 1. Demographic sample characteristics.

\begin{tabular}{cccc}
\hline Demographics & Category & Frequency & Percentage \\
\hline \multirow{4}{*}{ Gender } & Male & 231 & 42 \\
& Female & 319 & 58 \\
& Total & 550 & 100 \\
Age & $\leq 18$ & 51 & 9.3 \\
& $19-28$ & 158 & 28.7 \\
& $29-38$ & 306 & 55.6 \\
& $\geq 39$ & 35 & 6.4 \\
& Total & 550 & 100 \\
Educational level & Senior high school or below & 12 & 2.2 \\
& Associate degree & 34 & 6.2 \\
& Bachelor's degree & 416 & 75.6 \\
& Master's or higher degree & 88 & 16 \\
Experience in MOOC & Total & 550 & 100 \\
& Less than 6 months & 192 & 34.9 \\
& 6-12 months & 313 & 56.9 \\
& More than 1 year & 45 & 8.2 \\
& Total & 550 & 100 \\
MOOC platforms & Coursera & 141 & 25.6 \\
& Edex & 44 & 8 \\
& Udacity & 78 & 14.2 \\
& Icourse163 & 287 & 52.2 \\
& Total & 550 & 100 \\
\hline
\end{tabular}




\section{Results}

Before statistical analysis, the normality and multicollinearity of the data were tested. The maximum absolute value of skewness was 0.832 , less than 2 , and the maximum absolute value of kurtosis was 1.962 , less than 5 , so the data conformed to a normal distribution [83]. In order to test whether the data had multicollinearity, the variance inflation factor (VIF) was calculated. The results showed that the maximum VIF value of all variables was 2.127 , much lower than the recommended threshold of 10 , which suggested that the data had no serious collinearity problems [84]. In addition, considering that common-method variance (CMV) may threaten the validity of the data, the Harman's single factor test was adopted to detect the CMV [85]. It was found that the variance explanation rate of the first factor was $35.081 \%$, which is less than $50 \%$, suggesting that CMV had little effect on the results of this study.

\subsection{Measurement Model}

In order to verify the validity and accuracy of the data collected, this study tested the reliability and convergent validity of the measurement model built. It is generally believed in the field of social science that Cronbach's alpha $>0.7$ and composite reliability (CR) > 0.7 , suggesting that the measurement items of the potential constructs have good internal consistency. Convergent validity is mainly tested by the average variance extracted (AVE) value; that is, when an AVE value greater than 0.5 indicates that the measurement items have satisfactory convergent validity [86,87]. The analysis results of the measurement model showed that the Cronbach's alpha value and factor load of all the constructs in this study were greater than 0.7 , and the CR and AVE values were also acceptable (See Table 2). These suggest that the measurement items have satisfactory reliability and validity [87].

Table 2. Convergent validity and reliability.

\begin{tabular}{|c|c|c|c|c|c|c|}
\hline Construct & Item & $\begin{array}{l}\text { Factor } \\
\text { Loading }\end{array}$ & SMC & CR & AVE & $\begin{array}{c}\text { Cronbach's } \\
\text { Alpha }\end{array}$ \\
\hline \multirow{5}{*}{$\begin{array}{l}\text { Information } \\
\text { Quality }\end{array}$} & INFQ1 & 0.744 & 0.553 & \multirow{5}{*}{0.896} & \multirow{5}{*}{0.684} & \multirow{5}{*}{0.893} \\
\hline & INFQ2 & 0.917 & 0.840 & & & \\
\hline & INFQ3 & 0.876 & 0.767 & & & \\
\hline & INFQ4 & 0.757 & 0.573 & & & \\
\hline & SYSQ1 & 0.895 & 0.800 & & & \\
\hline System & SYSQ2 & 0.934 & 0.872 & \multirow{3}{*}{0.897} & \multirow{3}{*}{0.688} & \multirow{3}{*}{0.887} \\
\hline \multirow[t]{3}{*}{ Quality } & SYSQ33 & 0.753 & 0.567 & & & \\
\hline & SYSQ44 & 0.714 & 0.510 & & & \\
\hline & SERQ̄1 & 0.653 & 0.427 & \multirow{5}{*}{0.825} & \multirow{4}{*}{0.543} & \multirow{4}{*}{0.797} \\
\hline Service & SERQ22 & 0.835 & 0.697 & & & \\
\hline \multirow[t]{3}{*}{ Quality } & SERQ3 & 0.675 & 0.456 & & & \\
\hline & SERQ4 & 0.771 & 0.594 & & & \\
\hline & CONF1 & 0.809 & 0.654 & & \multirow{4}{*}{0.591} & \multirow{4}{*}{0.841} \\
\hline \multirow{3}{*}{ Confirmation } & CONF2 & 0.811 & 0.658 & \multirow{3}{*}{0.852} & & \\
\hline & CONF3 & 0.678 & 0.460 & & & \\
\hline & CONF4 & 0.768 & 0.590 & & & \\
\hline & PU1 & 0.781 & 0.610 & \multirow{5}{*}{0.838} & \multirow{5}{*}{0.565} & \multirow{5}{*}{0.835} \\
\hline Perceived & PU2 & 0.702 & 0.493 & & & \\
\hline \multirow[t]{3}{*}{ Usefulness } & PU3 & 0.792 & 0.627 & & & \\
\hline & PU4 & 0.728 & 0.530 & & & \\
\hline & SAT1 & 0.805 & 0.648 & & & \\
\hline \multirow{4}{*}{ Satisfaction } & SAT2 & 0.787 & 0.619 & \multirow{4}{*}{0.873} & \multirow{4}{*}{0.633} & \multirow{3}{*}{0.873} \\
\hline & SAT3 & 0.791 & 0.625 & & & \\
\hline & SAT4 & 0.799 & 0.638 & & & \\
\hline & CI1 & 0.763 & 0.582 & & & \multirow{4}{*}{0.833} \\
\hline Continuance & $\mathrm{CI} 2$ & 0.718 & 0.516 & \multirow{3}{*}{0.835} & \multirow{3}{*}{0.559} & \\
\hline \multirow[t]{2}{*}{ Intention } & $\mathrm{CI} 3$ & 0.767 & 0.588 & & & \\
\hline & $\mathrm{CI} 4$ & 0.740 & 0.548 & & & \\
\hline
\end{tabular}


Discrimination validity refers to the low correlation and significant difference between latent variables, and it can be evaluated by comparing AVE square root and correlation coefficients between variables. If the correlation coefficient of a variable with another one is smaller than the square root of the average variance of the variable, it indicates that the discrimination validity of the variable is good [86]. According to the analysis results in Table 3, all potential variables had a square root of AVE larger than their correlation coefficients, suggesting that the measurement model built in this study has good discrimination validity. Meanwhile, in terms of the degree of fitting of the model, CMIN/DF $=1.393$, $\mathrm{TLI}=0.983, \mathrm{CFI}=0.985, \mathrm{GFI}=0.945, \mathrm{NFI}=0.949, \mathrm{RMSEA}=0.027$, all results higher than the recommended thresholds [88]. This suggests that the measurement model built has a good degree of fitting.

Table 3. Discriminant validity.

\begin{tabular}{cccccccc}
\hline Construct & INFQ & SYSQ & SERQ & CONF & PU & SAT & CI \\
\hline INFQ & $\mathbf{0 . 8 2 7}$ & & & & & & \\
SYSQ & 0.310 & $\mathbf{0 . 8 2 9}$ & & & & & \\
SERQ & 0.277 & 0.214 & $\mathbf{0 . 7 3 7}$ & & & & \\
CONF & 0.547 & 0.376 & 0.519 & $\mathbf{0 . 7 6 9}$ & & & \\
PU & 0.494 & 0.458 & 0.614 & 0.628 & $\mathbf{0 . 7 5 2}$ & & \\
SAT & 0.391 & 0.470 & 0.343 & 0.663 & 0.669 & $\mathbf{0 . 7 9 6}$ & \\
CI & 0.375 & 0.398 & 0.390 & 0.323 & 0.702 & 0.678 & $\mathbf{0 . 7 4 8}$ \\
\hline
\end{tabular}

Note: The bolded numbers on the diagonal are the square root of AVE. INFQ: Information quality; SYSQ: System quality; SERQ: Service quality, CONF: Confirmation; PU: Perceived usefulness, SAT: Satisfaction; CI: Continuance intention.

\subsection{Structural Model}

After verifying the measurement model, we performed modeling using structural equations and tested the relationship between latent variables. The fitting indicators of the built structural model are as shown below: $\mathrm{CMIN} / \mathrm{DF}=1.477, \mathrm{TLI}=0.976, \mathrm{CFI}=0.979$, $\mathrm{GFI}=0.931, \mathrm{NFI}=0.939, \mathrm{RMSEA}=0.029$; all fitness indicators of the structural model were higher than the recommended thresholds [89]. This suggests that the model has a good degree of fitting. According to the analysis results of the structural model, all hypotheses proposed in this study are valid. Figure 2 presents the path relationships and explanatory variances of all hypotheses of the structural model, and Table 4 summarizes the results of the above hypotheses.

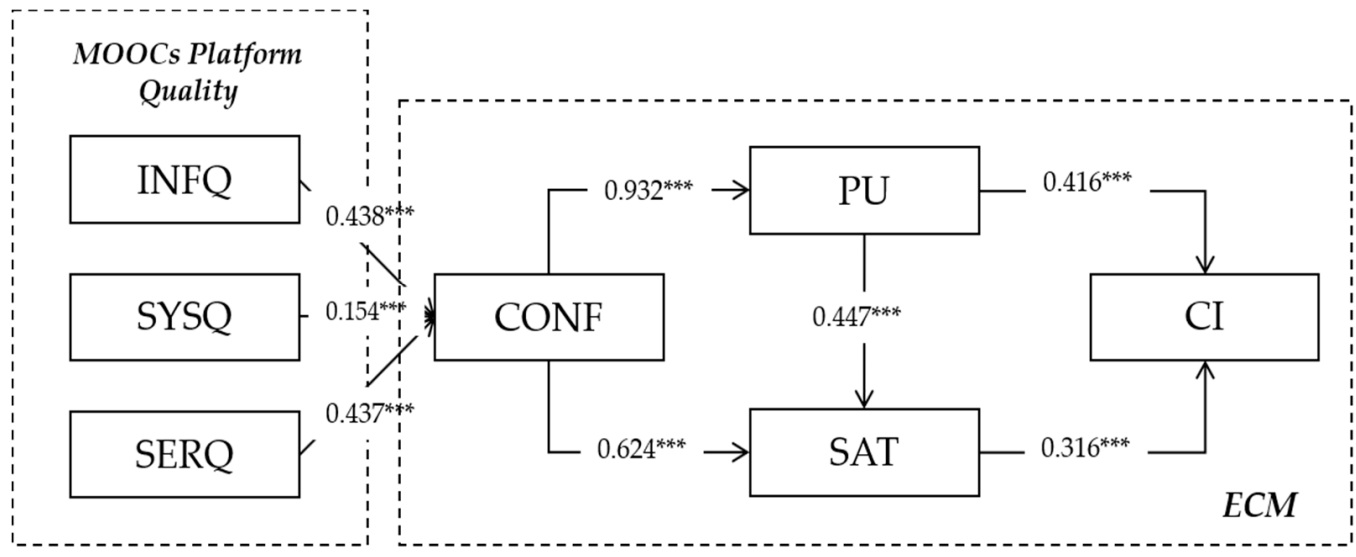

Figure 2. Results of the research model. Note: ${ }^{* * *} p<0.01$; INFQ: Information quality, SYSQ: System quality, SERQ: Service quality, CONF: Confirmation, PU: Perceived usefulness, SAT: Satisfaction, and CI: Continuance Intention. 
Table 4. Influence paths and hypotheses results.

\begin{tabular}{cccccc}
\hline Hypotheses & Path & Path Coefficient & $\boldsymbol{t}$-Value & $\boldsymbol{p}$-Value & Result \\
\hline H1 & INFQ $\rightarrow$ CONF & 0.438 & 8.593 & $* * *$ & Supported \\
H2 & SYSQ $\rightarrow$ CONF & 0.154 & 5.671 & $* * *$ & Supported \\
H3 & SERQ $\rightarrow$ CONF & 0.437 & 8.326 & $* * *$ & Supported \\
H4 & CONF $\rightarrow$ PU & 0.932 & 12.785 & $* * *$ & Supported \\
H5 & CONF $\rightarrow$ SAT & 0.624 & 6.633 & $* * *$ & Supported \\
H6 & PU $\rightarrow$ SAT & 0.447 & 6.662 & $* * *$ & Supported \\
H7 & PU $\rightarrow$ CI & 0.416 & 7.101 & $* * *$ & Supported \\
H8 & SAT $\rightarrow$ CI & 0.316 & 6.225 & $* * *$ & Supported \\
\hline Note: *** $p<0$ 01 INFQ $:$ Information
\end{tabular}

PU: Perceived usefulness, SAT: Satisfaction, CI: Continuance intention.

\section{Discussion}

The purpose of this study is to explore the factors affecting users' continuance intention to use MOOC platforms. With the D\&M ISS model and the ECM as the theoretical basis, this study built a research model and performed an empirical analysis of the hypotheses in the research model built in a structural manner. Analysis results showed that all the eight hypotheses proposed are valid. In this section, we discuss the key findings and implications of the hypothetical model's analysis results.

First, expectation confirmation was significantly influenced by the MOOC platforms' information quality $(\beta=0.438, p<0.01)$, system quality $(\beta=0.154, p<0.01)$, and service quality $(\beta=0.437, p<0.01)$. Information quality, system quality, and service quality explained $54.6 \%$ of the variation in users' confirmation. Analysis results provided strong support for $\mathrm{H} 1, \mathrm{H} 2$, and $\mathrm{H} 3$. The results showed that satisfactorily high-quality information, systems, and services provided by an MOOC platform effectively facilitate the formation of users' initial expectation toward it. Therefore, platform quality is a key factor affecting users' adoption for a MOOC platform [90], which is consistent with previous research results $[38,39,44]$.

In addition, expectation confirmation had a significant effect on both perceived usefulness $(\beta=0.932, p<0.01)$ and user satisfaction $(\beta=0.624, p<0.01)$. Therefore, $\mathrm{H} 4$ and $\mathrm{H} 5$ are backed, which is consistent with previous ECM-related research results [33,37,39]. Our results showed that expectation confirmation positively affects the perceived performance of MOOC platforms, including enhancing perceived usefulness and user satisfaction $[40,71,91]$. To note, this finding has also been confirmed in related research on e-learning. For example, the research by Dai et al. [36] suggested that perceived usefulness of an MOOC platform, in fact, is a manifestation of initial expectations confirmed after the platform is adopted, while the confirmation degree of initial expectations completely influences user satisfaction. Therefore, positive expectation confirmation is an important prerequisite for promoting users' continuance intention to use MOOC platforms.

In the end, perceived usefulness of MOOC platforms was found to positively influence user satisfaction $(\beta=0.447, p<0.01)$ and continuance intention $(\beta=0.416, p<0.01)$, while user satisfaction affected continuance intention $(\beta=0.316, p<0.01)$, thereby supporting H6, $\mathrm{H} 7$, and H8. These findings are consistent with the results of the studies on continuance intention to use IS $[40,43,76,79]$. Perceived usefulness and user satisfaction have been reconfirmed as key factors affecting continuance intention. Research results showed that if a MOOC platform brings actual improvement in personal performance, users will generate affirmative psychological feedback to the platform, which in turn uplifts users' continuance intention to use the MOOC platform.

\section{Implications}

\subsection{Theoretical Implications}

Theoretically, this study extends the information quality, system quality, and service quality constructed in the D\&M ISS model into the original ECM and takes them as the preceding factors affecting expectation confirmation, making up for the insufficiency in 
explanation of the original ECM for expectation confirmation. We verified the theoretical model using a structural model and found that all hypotheses proposed in this study are valid. Furthermore, the integrated ECM explained $54.3 \%$ of the variation in continuance intention, a remarkable increase compared with 41\% explained by the original ECM [33]. Although the effectiveness of the extended ECM for users' continuance intention in industries such as e-government, ERP, and mobile payment has been repeatedly confirmed, to our knowledge, this paper is the first empirical study that applies the extended ECM to MOOC platforms. Therefore, our findings are expected to provide a new perspective for the application of ECM to the sustainable research on MOOC.

\subsection{Practical Implications}

This research is of significant practical value for MOOC providers to develop effective strategies to improve platform functions and boost the degree of participation of learners. From the perspective of MOOC platform operators, grasping users' actual needs and designing functions and systems that meet user expectations are key factors affecting the initial operation of MOOC platforms. Study results have indicated that superior platform quality (e.g., information quality, system quality, and service quality) plays a positive role in promoting the formation of users' initial expectations. Therefore, MOOC operators should pay attention to the quality maintenance of MOOC platforms. First, while making sure that the system is reliable and safe [31], MOOC platform operators should strive to develop system functions on the basis of having a clear understanding of users' actual needs, with the goal of perfecting teaching processes and improving learning outcomes.

Moreover, apart from providing teacher profile and curriculum-related information, efforts should be made to establish an effective evaluation mechanism for teachers and courses. The mechanism may include, for example, scoring for teachers and courses, and individual teaching characteristics of teachers, so as to provide references for potential users to choose courses or for teachers to learn from each other. Moreover, sufficient attention should be given to expectation confirmation that acts as a key preceding factor affecting continuance use. MOOC platform operators are suggested to establish and maintain close relationships with users while emphasizing platform practicality, with the goal of timely understanding users' expectations and needs for courses and systems. Additionally, they should honestly acknowledge the actual performance and limitations of their courses or services developed, avoiding exaggerated publicity. This is because unrealistic initial expectations brought about by exaggerated publicity go against the formation of perceived usefulness and satisfaction and thus negatively affect users' continuance intention.

\section{Conclusions}

As an innovative educational model, MOOC is being increasingly accepted, but the high dropout rate has turned out to be a barrier to its sustainable development. For this reason, we attempted to identify the key factors affecting users' continuance intention to use MOOC platforms from the perspective of information systems. First, we extended the constructs of the D\&M ISS model (including information quality, system quality, and service quality) to the initial ECM, in an attempt to make up for the insufficient explanation of the original ECM for the external factors of expectation confirmation. Then, with the help of the modified ECM that integrated the quality factors in the D\&M ISS model, we verified the tenability of the hypotheses proposed using a structural approach. Our research results suggested that (1) the information quality, system quality, and service quality of MOOC platforms have an impact on expectation confirmation, of which service quality has the largest impact; (2) perceived usefulness and user satisfaction are the key factors affecting users' continuance intention to use MOOC platforms; and (3) the theoretical model that combines the D\&M ISS model and the ECM outperforms the original ECM in explaining the variation in continuance intention. In view of the above, MOOC platform operators are recommended to pay attention to platform quality, in an attempt to achieve users' expectation confirmation after adoption. Meanwhile, they are advised to take a 
cautious attitude towards promotion and advisement to avoid expectation deviation that is considered to affect users' continuance intention.

This study has some limitations. First, despite the satisfactory validity and reliability of the research model built, this study, similar to other studies using a survey-based method, is subject to a limited size of samples. The respondents mostly fell into the age group of 25-35 years, leading to the research model having an insufficient explanation for users aged 45 years and higher. Meanwhile, all respondents were Chinese, so the applicability of the research model in other countries or regions needs to be verified. Furthermore, in terms of the research model, the constructs of this study mostly come from the D\&M ISS model and the ECM, failing to take into account the impact of other important variables to continuance intention, such as course types, user habits, and trust. Therefore, the model should be further expanded in future studies, with the goal of better clarifying the complex relations between MOOC platforms and users' continuance intention to use them.

Author Contributions: Conceptualization, W.G., Y.X. and Z.-J.S.; methodology, W.G. and Y.X.; software, W.G. and Y.X.; formal analysis, W.G.; investigation, W.G., Y.X. and Z.-J.S.; data curation, Y.X.; writing — original draft preparation, W.G. and Y.X.; writing—review and editing, W.G., Y.X. and Z.J.S. All authors have read and agreed to the published version of the manuscript.

Funding: This research received no external funding.

Institutional Review Board Statement: Not applicable.

Informed Consent Statement: Informed consent was obtained from all subjects involved in the study.

Data Availability Statement: Not applicable.

Conflicts of Interest: The authors declare no conflict of interest.

\section{Appendix A}

Table A1. The Study's Measurement Items.

\begin{tabular}{|c|c|}
\hline & MOOC platform provides accurate information. \\
\hline Information & MOOC platform provides clear information. \\
\hline \multirow[t]{3}{*}{ Quality } & MOOC platform provides relevant information. \\
\hline & MOOC platform provides up-to-date information. \\
\hline & It is convenient (easy to use) to access MOOC platform system. \\
\hline System & MOOC platform system is reliable. \\
\hline \multirow[t]{2}{*}{ Quality } & MOOC platform system is flexible (user-friendly). \\
\hline & MOOC platform system allows information to be readily accessible to me. \\
\hline Service & MOOC platform provides right solution to my request. \\
\hline \multirow[t]{3}{*}{ Quality } & The service provided in MOOC platform attends to individual's personalized needs. \\
\hline & The service provided in MOOC platform is reliable. \\
\hline & My experience with using the MOOC platform was better than I expected. \\
\hline \multirow{4}{*}{ Confirmation } & My expectations from using the MOOC platform were confirmed. \\
\hline & The service level provided by the MOOC platform was better than I expected. \\
\hline & The MOOC platform can meet demands in excess of what I required for the service. \\
\hline & The MOOC platform benefits me. \\
\hline Perceived & The advantages of the MOOC platform outweigh the disadvantages. \\
\hline \multirow[t]{3}{*}{ Usefulness } & Using a MOOC platform helps me accomplish tasks more quickly. \\
\hline & Overall, using a MOOC platform is advantageous. \\
\hline & I am extremely pleased with the MOOC platform. \\
\hline \multirow{4}{*}{ Satisfaction } & I am extremely contented with the MOOC platform. \\
\hline & I am extremely satisfied with the MOOC platform. \\
\hline & I am absolutely delighted with the MOOC platform. \\
\hline & I intend to continue using the MOOC platform in future. \\
\hline \multirow{3}{*}{$\begin{array}{l}\text { Continuance } \\
\text { intention }\end{array}$} & I intend to continue using MOOC platform rather than using any alternative means. \\
\hline & I will continue using the MOOC platform in future. \\
\hline & I strongly recommend others to use MOOC platform. \\
\hline
\end{tabular}




\section{References}

1. Becker, G. Climate change education for sustainable development in urban educational landscapes and learning cities. Experiences perspectives from Osnabrück. In Lifelong Learning and Education in Healthy and Sustainable Cities; Springer: Cham, Switzerland, 2017; pp. 439-469. [CrossRef]

2. Nousheen, A.; Zai, S.A.Y.; Waseem, M.; Khan, S.A. Education for sustainable development (ESD): Effects of sustainability education on pre-service teachers' attitude towards sustainable development (SD). J. Clean. Prod. 2020, 250, 119537. [CrossRef]

3. McKeown, R.; Hopkins, C.A.; Rizi, R.; Chrystalbridge, M. Education for Sustainable Development Toolkit; Energy, Environment and Resources Center, University of Tennessee: Knoxville, TN, USA, 2002.

4. Buckler, C.; Creech, H. Shaping the Future We Want: UN Decade of Education for Sustainable Development; Final Report; UNESCO: Paris, France, 2014.

5. Beynaghi, A.; Trencher, G.; Moztarzadeh, F.; Mozafari, M.; Maknoon, R.; Filho, W.L. Future sustainability scenarios for universities: Moving beyond the United Nations Decade of Education for Sustainable Development. J. Clean. Prod. 2016, 112, 3464-3478. [CrossRef]

6. Chow, W.S.; Shi, S. Investigating Students' Satisfaction and Continuance Intention toward E-learning: An Extension of the Expectation-Confirmation Model. Procedia Soc. Behav. Sci. 2014, 141, 1145-1149. [CrossRef]

7. Sarabadani, J.; Jafarzadeh, H.; ShamiZanjani, M. Towards Understanding the Determinants of Employees' E-Learning Adoption in Workplace: A Unified Theory of Acceptance and Use of Technology (UTAUT) View. Int. J. Enterp. Inf. Syst. 2017, 13, 38-49. [CrossRef]

8. Tsai, C.-W.; Shen, P.-D.; Chiang, Y.-C. The application of mobile technology in e-learning and online education environments: A review of publications in SSCI-indexed journals from 2003 to 2012. Int. J. Enterp. Inf. Syst. 2013, 9, 85-98. [CrossRef]

9. Wu, B. Identifying the Influential Factors of Knowledge Sharing in E-Learning 2.0 Systems. Int. J. Enterp. Inf. Syst. 2016, 12, 85-102. [CrossRef]

10. Al-Fraihat, D.; Joy, M.; Masa'Deh, R.; Sinclair, J. Evaluating E-learning systems success: An empirical study. Comput. Hum. Behav. 2019, 102, 67-86. [CrossRef]

11. Fazlollahtabar, H.; Muhammadzadeh, A. A Knowledge-Based User Interface to Optimize Curriculum Utility in an E-Learning System. Int. J. Enterp. Inf. Syst. 2012, 8, 34-53. [CrossRef]

12. Kilburn, A.; Kilburn, B.; Cates, T. Drivers of student retention: System availability, privacy, value and loyalty in online higher education. Acad. Educ. Leadersh. J. 2014, 18, 1-14.

13. Joo, Y.J.; So, H.-J.; Kim, N.H. Examination of relationships among students' self-determination, technology acceptance, satisfaction, and continuance intention to use K-MOOCs. Comput. Educ. 2018, 122, 260-272. [CrossRef]

14. Ossiannilsson, E.; Altinay, F.; Altinay, Z. MOOCs as Change Agents to Boost Innovation in Higher Education Learning Arenas. Educ. Sci. 2016, 6, 25. [CrossRef]

15. Hollenbeck, C.R.; Zinkhan, G.M.; French, W. Distance Learning Trends and Benchmarks: Lessons from an Online MBA Program. Mark. Educ. Rev. 2005, 15, 39-52. [CrossRef]

16. Shah, D. Year of MOOC-Based Degrees: A Review of MOOC Stats and Trends in 2018. Class Central. Available online: https:/ / www.classcentral.com/report/moocs-stats-and-trends-2018 (accessed on 6 June 2019).

17. Ministry of Education of the People's Republic of China. Opinions on Strengthening Construction, Application and Management of Online Open Courses in Colleges and Universities. 2015. Available online: http://www.moe.gov.cn/srcsite/A08/s7056/2015 04/t20150416_189454.html (accessed on 6 May 2019).

18. Ho, A.; Chuang, I.; Reich, J.; Coleman, C.; Whitehill, J.; Northcutt, C.; Williams, J.; Hansen, J.; Lopez, G.; Petersen, R. HarvardX and MITx: Two Years of Open Online Courses Fall 2012-Summer 2014. SSRN Electron. J. 2015. Available online: https: / / papers.ssrn.com/sol3 / papers.cfm?abstract_id=2586847 (accessed on 9 October 2021).

19. Jordan, K. Initial trends in enrolment and completion of massive open online courses. Int. Rev. Res. Open Distrib. Learn. 2014, 15, 133-160. [CrossRef]

20. Kolowich, S. The professors who make the MOOCs. Chron. High. Educ. 2013, 25. Available online: http://publicservicesalliance. org/wp-content/uploads/2013/03/The-Professors-Behind-the-MOOC-Hype-Technology-The-Chronicle-of-Higher-Education. pdf (accessed on 20 May 2019).

21. Hew, K.F.; Cheung, W.S. Students' and instructors' use of massive open online courses (MOOCs): Motivations and challenges. Educ. Res. Rev. 2014, 12, 45-58. [CrossRef]

22. Alraimi, K.M.; Zo, H.; Ciganek, A.P. Understanding the MOOCs continuance: The role of openness and reputation. Comput. Educ. 2015, 80, 28-38. [CrossRef]

23. Delgado-Algarra, E.J.; Sánchez, I.M.R.; Olmedo, E.O.; Lorca-Marín, A.A. International MOOC Trends in Citizenship, Participation and Sustainability: Analysis of Technical, Didactic and Content Dimensions. Sustainability 2019, 11, 5860. [CrossRef]

24. Lee, M.-C. Explaining and predicting users' continuance intention toward e-learning: An extension of the expectation-confirmation model. Comput. Educ. 2010, 54, 506-516. [CrossRef]

25. Tarhini, A.; Masa'Deh, R.; Al-Busaidi, K.A.; Mohammed, A.B.; Maqableh, M. Factors influencing students' adoption of e-learning: A structural equation modeling approach. J. Int. Educ. Bus. 2017, 10, 164-182. [CrossRef]

26. Chiu, C.-M.; Hsu, M.-H.; Sun, S.-Y.; Lin, T.-C.; Sun, P.-C. Usability, quality, value and e-learning continuance decisions. Comput. Educ. 2005, 45, 399-416. [CrossRef] 
27. Yuan, L.; Powell, S. MOOCs and Open Education: Implications for Higher Education; Cetis: Lancashire, UK, 2013.

28. Xiong, Y.; Li, H.; Kornhaber, M.L.; Suen, H.K.; Pursel, B.; Goins, D.D. Examining the relations among student motivation, engagement, and retention in a MOOC: A structural equation modeling approach. Glob. Educ. Rev. 2015, 2, 23-33.

29. Magen-Nagar, N.; Cohen, L. Learning strategies as a mediator for motivation and a sense of achievement among students who study in MOOCs. Educ. Inf. Technol. 2016, 22, 1271-1290. [CrossRef]

30. Hoxby, C.M. The Economics of Online Postsecondary Education: MOOCs, Nonselective Education, and Highly Selective Education. Am. Econ. Rev. 2014, 104, 528-533. [CrossRef]

31. Al-Adwan, A.S.; Albelbisi, N.A.; Hujran, O.; Al-Rahmi, W.M.; Alkhalifah, A. Developing a Holistic Success Model for Sustainable E-Learning: A Structural Equation Modeling Approach. Sustainability 2021, 13, 9453. [CrossRef]

32. Delone, W.H.; McLean, E.R. Measuring e-Commerce Success: Applying the DeLone \& McLean Information Systems Success Model. Int. J. Electron. Commer. 2004, 9, 31-47. [CrossRef]

33. Bhattacherjee, A. Understanding Information Systems Continuance: An Expectation-Confirmation Model. MIS Q. 2001, 25, 351-370. [CrossRef]

34. Aparicio, M.; Oliveira, T.; Bacao, F.; Painho, M. Gamification: A key determinant of massive open online course (MOOC) success. Inf. Manag. 2019, 56, 39-54. [CrossRef]

35. Albelbisi, N.A.; Al-Adwan, A.S.; Habibi, A. Impact of Quality Antecedents on Satisfaction Toward MOOC. Turk. Online J. Distance Educ. 2021, 22, 164-175. [CrossRef]

36. Dai, H.M.; Teo, T.; Rappa, N.A.; Huang, F. Explaining Chinese university students' continuance learning intention in the MOOC setting: A modified expectation confirmation model perspective. Comput. Educ. 2020, 150, 103850. [CrossRef]

37. Kim, B. An empirical investigation of mobile data service continuance: Incorporating the theory of planned behavior into the expectation-confirmation model. Expert Syst. Appl. 2010, 37, 7033-7039. [CrossRef]

38. Roca, J.C.; Chiu, C.-M.; Martínez, F.J. Understanding e-learning continuance intention: An extension of the Technology Acceptance Model. Int. J. Hum.-Comput. Stud. 2006, 64, 683-696. [CrossRef]

39. Cheng, Y.-M. Extending the expectation-confirmation model with quality and flow to explore nurses' continued blended e-learning intention. Inf. Technol. People 2014, 27, 230-258. [CrossRef]

40. Gupta, A.; Yousaf, A.; Mishra, A. How pre-adoption expectancies shape post-adoption continuance intentions: An extended expectation-confirmation model. Int. J. Inf. Manag. 2020, 52, 102094. [CrossRef]

41. Zhang, M.; Liu, Y.; Yan, W.; Zhang, Y. Users' continuance intention of virtual learning community services: The moderating role of usage experience. Interact. Learn. Environ. 2016, 25, 685-703. [CrossRef]

42. Park, E. User acceptance of smart wearable devices: An expectation-confirmation model approach. Telemat. Inform. 2020, 47, 101318. [CrossRef]

43. Veeramootoo, N.; Nunkoo, R.; Dwivedi, Y. What determines success of an e-government service? Validation of an integrative model of e-filing continuance usage. Gov. Inf. Q. 2018, 35, 161-174. [CrossRef]

44. Akram, M.S.; Malik, A.; Shareef, M.A.; Goraya, M.A.S. Exploring the interrelationships between technological predictors and behavioral mediators in online tax filing: The moderating role of perceived risk. Gov. Inf. Q. 2019, 36, 237-251. [CrossRef]

45. Mulder, F.; Jansen, D. MOOCs for opening up education and the OpenupEd Initiative. In MOOCs and Open Education around the World; Taylor \& Francis: London, UK, 2015; pp. 130-142. [CrossRef]

46. Shapiro, H.B.; Lee, C.H.; Roth, N.E.W.; Li, K.; Çetinkaya-Rundel, M.; Canelas, D.A. Understanding the massive open online course (MOOC) student experience: An examination of attitudes, motivations, and barriers. Comput. Educ. 2017, 110, 35-50. [CrossRef]

47. Haider, T. A Comprehensive List of MOOC (Massive Open Online Courses) Providers. TechnoDuet, 24 April 2013.

48. Rodriguez, O. The concept of openness behind c and x-MOOCs (Massive Open Online Courses). Open Prax. 2013, 5, 67-73. [CrossRef]

49. AlDahdouh, A.; Osorio, A.; Caires, S. Understanding knowledge network, learning and connectivism. Int. J. Instr. Technol. Distance Learn. 2015, 12, 3-21.

50. Walls, J.; Kelder, J.-A.; King, C.; Booth, S.; Sadler, D. Quality assurance for Massive Open Access Online Courses: Building on the old to create something new. In Macro-Level Learning through Massive Open Online Courses (MOOCs): Strategies and Predictions for the Future; IGI Global: Hershey, PA, USA, 2015; pp. 25-47.

51. Xiao, C.; Qiu, H.; Cheng, S.M. Challenges and opportunities for effective assessments within a quality assurance framework for MOOCs. J. Hosp. Leis. Sport Tour. Educ. 2018, 24, 1-16. [CrossRef]

52. Sunar, A.S.; Abbasi, R.A.; Davis, H.C.; White, S.; Aljohani, N.R. Modelling MOOC learners' social behaviours. Comput. Hum. Behav. 2018, 107, 105835. [CrossRef]

53. Zhu, M.; Sari, A.; Lee, M.M. A systematic review of research methods and topics of the empirical MOOC literature (2014-2016). Internet High. Educ. 2018, 37, 31-39. [CrossRef]

54. Wiley, D.; Hilton, J., III. Openness, Dynamic Specialization, and the Disaggregated Future of Higher Education. Int. Rev. Res. Open Distrib. Learn. 2009, 10. [CrossRef]

55. Knox, J. Digital culture clash: "Massive" education in the E-learning and Digital Cultures MOOC. Distance Educ. 2014, 35, 164-177. [CrossRef] 
56. Li, K.C.; Wong, B.T.; Chok, E.W.; Lee, T. Profiling MOOC platforms: Uniformity and diversity in course provision. In Studies and Practices for Advancement in Open and Distance Education; OUHK Press: Hong Kong, China, 2015; pp. 140-153.

57. de Waard, I.; Gallagher, M.S.; Zelezny-Green, R.; Czerniewicz, L.; Downes, S.; Kukulska-Hulme, A.; Willems, J. Challenges for conceptualising EU MOOC for vulnerable learner groups. In Proceedings of the European MOOC Stakeholder Summit 2014; Ecole Polytechnique Federale de Lausanne (Swiss Federal Institute of Technology in Lausanne): Lausanne, Switzerland, 2014; pp. 33-42.

58. Khan, I.U.; Hameed, Z.; Yu, Y.; Islam, T.; Sheikh, Z.; Khan, S.U. Predicting the acceptance of MOOCs in a developing country: Application of task-technology fit model, social motivation, and self-determination theory. Telemat. Inform. 2018, 35, 964-978. [CrossRef]

59. Lambert, S.R. Do MOOCs contribute to student equity and social inclusion? A systematic review 2014-18. Comput. Educ. 2019, 145, 103693. [CrossRef]

60. Delone, W.H.; McLean, E.R. Information Systems Success: The Quest for the Dependent Variable. Inf. Syst. Res. 1992, 3, 60-95. [CrossRef]

61. Mason, R.O. Measuring information output: A communication systems approach. Inf. Manag. 1978, 1, 219-234. [CrossRef]

62. Shannon, C.E. A mathematical theory of communication. Bell Syst. Tech. J. 1948, 27, 379-423. [CrossRef]

63. Chen, C.-W.D.; Cheng, C.-Y.J. Understanding consumer intention in online shopping: A respecification and validation of the DeLone and McLean model. Behav. Inf. Technol. 2009, 28, 335-345. [CrossRef]

64. Noudoostbeni, A.; Kaur, K.; Jenatabadi, H.S. A Comparison of Structural Equation Modeling Approaches with DeLone \& McLean's Model: A Case Study of Radio-Frequency Identification User Satisfaction in Malaysian University Libraries. Sustainability 2018, 10, 2532.

65. Albelbisi, N.A.; Al-Adwan, A.S.; Habibi, A. Self-regulated learning and satisfaction: A key determinants of MOOC success. Educ. Inf. Technol. 2021, 26, 3459-3481. [CrossRef]

66. Cidral, W.A.; Oliveira, T.; Di Felice, M.; Aparicio, M. E-learning success determinants: Brazilian empirical study. Comput. Educ. 2018, 122, 273-290. [CrossRef]

67. Calisir, F.; Altin Gumussoy, C.; Bayraktaroglu, A.E.; Karaali, D. Predicting the intention to use a web-based learning system: Perceived content quality, anxiety, perceived system quality, image, and the technology acceptance model. Hum. Factors Ergonom. Manuf. Serv. Ind. 2014, 24, 515-531. [CrossRef]

68. Wu, B.; Zhang, C. Empirical study on continuance intentions towards E-Learning 2.0 systems. Behav. Inf. Technol. 2014, 33, 1027-1038. [CrossRef]

69. Yang, M.; Shao, Z.; Liu, Q.; Liu, C. Understanding the quality factors that influence the continuance intention of students toward participation in MOOCs. Educ. Technol. Res. Dev. 2017, 65, 1195-1214. [CrossRef]

70. Oliver, R.L. A cognitive model of the antecedents and consequences of satisfaction decisions. J. Mark. Res. 1980, 17, 460-469. [CrossRef]

71. Liao, C.; Palvia, P.; Chen, J.-L. Information technology adoption behavior life cycle: Toward a Technology Continuance Theory (TCT). Int. J. Inf. Manag. 2009, 29, 309-320. [CrossRef]

72. Ambalov, I.A. A meta-analysis of IT continuance: An evaluation of the expectation-confirmation model. Telemat. Inform. 2018, 35, 1561-1571. [CrossRef]

73. Chou, S.-W.; Chen, P.-Y. The influence of individual differences on continuance intentions of enterprise resource planning (ERP). Int. J. Hum.-Comput. Stud. 2009, 67, 484-496. [CrossRef]

74. Hsu, C.-L.; Lin, J.C.-C. Effect of perceived value and social influences on mobile app stickiness and in-app purchase intention. Technol. Forecast. Soc. Chang. 2016, 108, 42-53. [CrossRef]

75. Kim, S.H.; Bae, J.H.; Jeon, H.M. Continuous Intention on Accommodation Apps: Integrated Value-Based Adoption and Expectation-Confirmation Model Analysis. Sustainability 2019, 11, 1578. [CrossRef]

76. Huang, Y.-M. Examining students' continued use of desktop services: Perspectives from expectation-confirmation and social influence. Comput. Hum. Behav. 2019, 96, 23-31. [CrossRef]

77. Petter, S.; Delone, W.; McLean, E. Measuring information systems success: Models, dimensions, measures, and interrelationships. Eur. J. Inf. Syst. 2008, 17, 236-263. [CrossRef]

78. Bhattacherjee, A.; Premkumar, G. Understanding Changes in Belief and Attitude toward Information Technology Usage: A Theoretical Model and Longitudinal Test. MIS Q. 2004, 28, 229. [CrossRef]

79. Daneji, A.A.; Ayub, A.F.M.; Khambari, M.N.M. The effects of perceived usefulness, confirmation and satisfaction on continuance intention in using massive open online course (MOOC). Knowl. Manag. E-Learn. Int. J. 2019, 11, 201-214. [CrossRef]

80. Hung, M.-C.; Chang, I.-C.; Hwang, H.-G. Exploring academic teachers' continuance toward the web-based learning system: The role of causal attributions. Comput. Educ. 2011, 57, 1530-1543. [CrossRef]

81. Lin, W.-S.; Wang, C.-H. Antecedences to continued intentions of adopting e-learning system in blended learning instruction: A contingency framework based on models of information system success and task-technology fit. Comput. Educ. 2012, 58, 88-99. [CrossRef]

82. Anderson, J.C.; Gerbing, D.W. Structural equation modeling in practice: A review and recommended two-step approach. Psychol. Bull. 1988, 103, 411. [CrossRef] 
83. Finney, S.J.; DiStefano, C. Non-normal and categorical data in structural equation modeling. In Structural Equation Modeling: A Second Course; Information Age Publishing: Greenwich, CT, USA, 2006; Volume 10, pp. 269-314.

84. Hair, J.F.; Celsi, M.; Ortinau, D.J.; Bush, R.P. Essentials of Marketing Research; McGraw-Hill/Irwin: New York, NY, USA, 2010.

85. MacKenzie, S.B.; Podsakoff, P.M. Common Method Bias in Marketing: Causes, Mechanisms, and Procedural Remedies. J. Retail. 2012, 88, 542-555. [CrossRef]

86. Fornell, C.; Larcker, D.F. Evaluating structural equation models with unobservable variables and measurement error. J. Mark. Res. 1981, 18, 39-50. [CrossRef]

87. George, D.; Mallery, P. IBM SPSS Statistics 23 Step by Step: A Simple Guide and Reference; Routledge: London, UK, 2016.

88. Hu, L.; Bentler, P.M. Cutoff criteria for fit indexes in covariance structure analysis: Conventional criteria versus new alternatives. Struct. Equ. Model. Multidiscip. J. 1999, 6, 1-55. [CrossRef]

89. Gefen, D.; Straub, D. A practical guide to factorial validity using PLS-Graph: Tutorial and annotated example. Commun. Assoc. Inf. Syst. 2005, 16, 5. [CrossRef]

90. Hassanzadeh, A.; Kanaani, F.; Elahi, S. A model for measuring e-learning systems success in universities. Expert Syst. Appl. 2012, 39, 10959-10966. [CrossRef]

91. Joo, Y.J.; Park, S.; Shin, E.K. Students' expectation, satisfaction, and continuance intention to use digital textbooks. Comput. Hum. Behav. 2017, 69, 83-90. [CrossRef] 